Article

\title{
How the Proximal Pocket May Influence the Enantiospecificities of Chloroperoxidase-Catalyzed Epoxidations of Olefins
}

\author{
Alexander N. Morozov * and David C. Chatfield * \\ Department of Chemistry and Biochemistry, Florida International University, \\ 11200 SW 8th St., Miami, FL 33199, USA \\ * Correspondence: omorozov@fiu.edu (A.N.M.); chatfiel@fiu.edu (D.C.C.); Tel.: +1-305-348-1198 (A.N.M.); \\ +1-305-348-3977 (D.C.C.)
}

Academic Editor: Samuel De Visser

Received: 27 June 2016; Accepted: 1 August 2016; Published: 9 August 2016

\begin{abstract}
Chloroperoxidase-catalyzed enantiospecific epoxidations of olefins are of significant biotechnological interest. Typical enantiomeric excesses are in the range of $66 \%-97 \%$ and translate into free energy differences on the order of $1 \mathrm{kcal} / \mathrm{mol}$. These differences are generally attributed to the effect of the distal pocket. In this paper, we show that the influence of the proximal pocket on the electron transfer mechanism in the rate-limiting event may be just as significant for a quantitatively accurate account of the experimentally-measured enantiospecificities.
\end{abstract}

Keywords: heme-thiolate enzymes; chloroperoxidase; cytochrome P450; Compound I; proximal pocket; hydrogen bonding; helix dipole; catalytic reactivity; epoxidation; density functional theory

\section{Introduction}

Chloroperoxidase (CPO), an enzyme secreted by the marine fungus Caldariomyces fumago, is a glycosylated heme-thiolate protein known for its exceptional versatility [1]. Along with its native function of halogenating organic substrates using chloride, bromide and iodide ions [2-4], CPO is also capable of many promiscuous activities, including peroxidase, catalase and cytochrome P450 (P450) types of reactions [1]. CPO-catalyzed reactions are of biotechnological and environmental importance [5], therefore attracting current research interest on both the experimental [6-14] and theoretical sides [15-21]. The catalytic cycle requires a two-electron oxidation of the ferric heme center, using hydrogen peroxide or other suitable peroxide, and the glutamic acid side chain $\left(\mathrm{E}_{183}\right)$ in the distal pocket as a general acid-base catalyst, to form Compound I (CPO-I), a highly reactive oxyferryl porphyrin $\pi$-cation radical intermediate $[15,20,22,23]$. This first step is followed by the oxidation of a substrate, and the reaction cycle ends as $\mathrm{CPO}$ regains the native state.

The active center of $\mathrm{CPO}$ has both peroxidase and $\mathrm{P} 450$ features: like a peroxidase, $\mathrm{CPO}$ has a polar pocket on the distal side of the heme; like P450, CPO possesses a cysteine-derived thiolate axial ligand on the proximal side [24]. CPO's distal pocket is connected to the protein surface by a roughly $10-\AA$ wide channel, similar to P450s' and with no analog in peroxidases [24,25]. In a previous computational study, we showed that $\mathrm{CPO}$ has the ability to mimic both peroxidase-like and P450-like distal pockets to tune the catalytic efficiency [18]. A key for the oxidative catalytic functions of CPO and P450s is the proximal thiolate ligand [24,26], which is a strong electron donor "pushing" electrons [27]. It took more than fifty years from the discovery of P450-type chemistry to establish that the "push" of the proximal thiolate results in a trade-off between the redox potential of the heme active center and the basicity of a distal axial ligand and, hence, constitutes a smart adaptation to the different stages of the reaction cycle $[28,29]$, facilitating both $\mathrm{O}-\mathrm{O}$ bond scission of a ferric hydroperoxy species $[15,20,30]$ 
and subsequent oxygen transfer into a $\mathrm{C}=\mathrm{C}$ double bond [31] or an inert $\mathrm{C}-\mathrm{H}$ bond $[28,29,32]$, as well as other oxygen transfer reactions $[1,33]$.

In heme-thiolate enzymes, the thiolate "push" is modulated by adjusting the thiolate-to-thiol character of the proximal ligand via sulfur/backbone-amide (NH-S) hydrogen bonds, a conserved feature of heme-thiolate proteins [34]. In CPO, the proximal thiolate ligand forms $\mathrm{A}_{31}: \mathrm{NH}-\mathrm{C}_{29}: \mathrm{S}$ and $\mathrm{L}_{32}: \mathrm{NH}-\mathrm{C}_{29}: \mathrm{S}$ hydrogen bonds (Figure 1) [24], made possible by the backbone conformation of the proximal pocket's C-P-A-L peptide fragment [35]. P450cam contains the peptide fragment C-L-G-X, conserved in P450s, which forms $\mathrm{L}_{358}: \mathrm{NH}-\mathrm{C}_{357}: \mathrm{S}, \mathrm{G}_{359}: \mathrm{NH}-\mathrm{C}_{357}: \mathrm{S}$ and $\mathrm{Q}_{360}: \mathrm{NH}-\mathrm{C}_{357}: \mathrm{S}$ thiolate sulfur/backbone-amide hydrogen bonds via a similar backbone conformation [35]. Recently, we have summarized an extensive set of experimental data available on the effect of proximal NH-S hydrogen bonding in P450cam [21]. Briefly, there is accumulating evidence that NH-S hydrogen bonds play a chemical role: (1) by modulating the thiolate "push" effect through the alteration of $\pi$-electron donation by the proximal thiolate [36]; (2) by modulating the heme reduction potential by up to $\sim 200 \mathrm{mV}$ per $\mathrm{NH}-\mathrm{S}$ hydrogen bond [36-38]. NH-S hydrogen bonds also play a structural role, in protecting and stabilizing Fe-S coordination [39]. On the theoretical side, calculations of the effect of proximal NH-S hydrogen bonds on oxidations catalyzed by a model heme-thiolate Compound I, using $(\mathrm{SH})^{-}$to represent the proximal ligand, indicate that $\mathrm{NH}-\mathrm{S}$ bonding has an influence on the chemoselectivity of Compound I toward hydroxylation vs. epoxidation [40,41]. Theoretical simulations of proximal pocket/sulfur hydrogen bonding in nitric oxide synthase showed that such bonding may affect the distribution of the thiolate/porphyrin unpaired spin [42]. The effect of hydrogen bonding to the distal oxygen of model manganese(IV)-oxo and iron(IV)-oxo oxidants on the oxidants' ability for oxygen atom transfer was studied [43]. However, to the best of our knowledge, there are no published theoretical results regarding the possibility that the proximal helix and the NH-S bonds may affect the enantiospecificity of oxidations catalyzed by heme-thiolate enzymes. In addition to NH-S hydrogen bonding, the electropositivity of the $\mathrm{N}$-terminus of the proximal $\alpha$-helix also modulates the anionic character of the proximal thiolate ligand in $\mathrm{CPO}$ and P450 [34]. The helix dipole moment is in the range of 3.5-5 D per peptide residue, according to both experiment and theoretical calculation [44,45]. Elements of secondary structure are known to play mechanistic roles in folding and post-translational modification of heme-containing proteins [46-49]. The electric field at helix termini is strong enough to influence protein folding, ligand binding and enzymatic reactions [44,50]. Experimental studies of heme-thiolate model complexes showed that adding the proximal helix to a model compound increases the $\mathrm{Fe}{ }^{\mathrm{III} / \mathrm{II}}$ redox potential by $130 \mathrm{mV}$ for a CPO model and by $70 \mathrm{mV}$ for a P450cam model [51]. In view of this, it is not surprising that the proximal helix may amplify the NH-S effect in heme-thiolate enzymes, as experiments suggest [51].
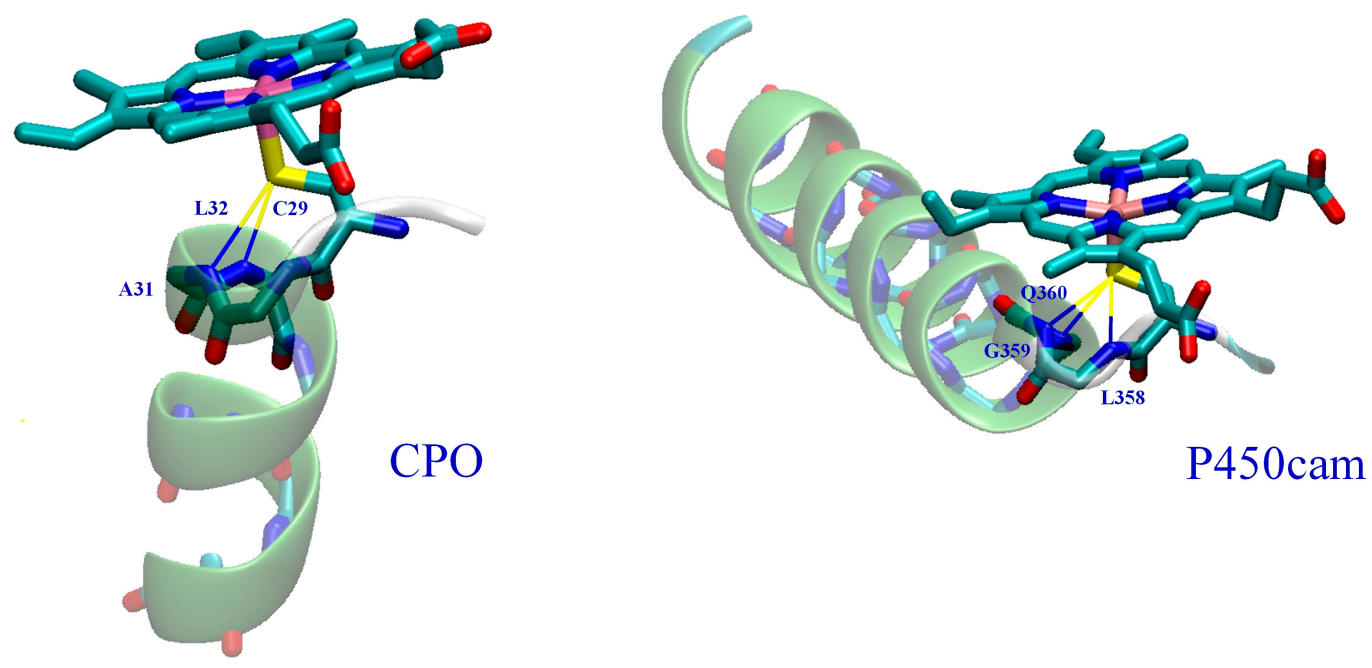

Figure 1. Proximal pockets of CPO and P450cam. 
CPO's ability to catalyze P450-type enantiospecific epoxidations of olefin substrates [52,53] is of particular interest, as chiral epoxides are synthons for various pharmaceutical and industrial applications. The experimental data described above suggest that the heme thiolate's secondary coordination sphere and the proximal helix are of importance for epoxidations catalyzed by heme-thiolate enzymes. Our recent DFT studies provide theoretical evidence that the combined effect of the proximal NH-S bonds and the dipole moment of the proximal helix significantly enhances CPO's reactivity toward the epoxidation of olefinic substrates [21]. When the environment of the proximal thiolate ligand (Figure $2 \mathrm{~B}$ ) is included in the model, the rate limiting barrier for $\mathrm{C}-\mathrm{O}$ bond formation on the doublet spin surface for $\mathrm{CPO}$-catalyzed epoxidation of cis- $\beta$-methylstyrene (CBMS) to form the $1 \mathrm{~S} 2 \mathrm{R}$ enantiomer is lowered by $\sim 4.6 \mathrm{kcal} / \mathrm{mol}$ relative to the $\sim 15 \mathrm{kcal} / \mathrm{mol}$ barrier for the bare-thiolate model (Figure 2A). In this nomenclature, the alpha carbon is labeled 1 and followed by its chirality, here $\mathrm{S}$, while the beta carbon is labeled 2 and followed by its chirality, here R. It was estimated that the dipole moment of the proximal helix contributes $\sim 1 / 3$ of the decrease [21]. For the 1S2R enantiomer on the doublet spin surface, we found that the effects of CPO's proximal pocket change the preferred electron transfer mechanism. For the bare thiolate model of CPO-I, the first and rate-limiting event is the reduction of $\mathrm{Fe}^{\mathrm{IV}}$ to $\mathrm{Fe}{ }^{\mathrm{III}}$ by an electron transferred from the $\mathrm{C}=\mathrm{C} \pi$ bond to the oxyferryl $\pi^{*}$ orbital. With the proximal pocket added to the model, though, the reduction of the porphyrin moiety via electron transfer to the $\mathrm{a}_{2 \mathrm{u}}+\sigma_{S}$ orbital is the first and rate-limiting event [21]. A detailed description of the orbitals important for the reactivity of heme thiolate enzymes can be found elsewhere [21,54].

a)

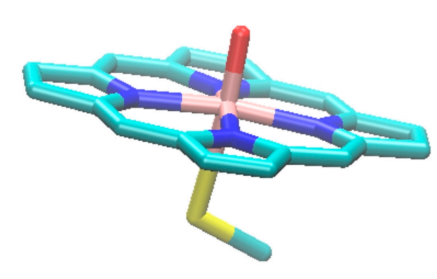

b)

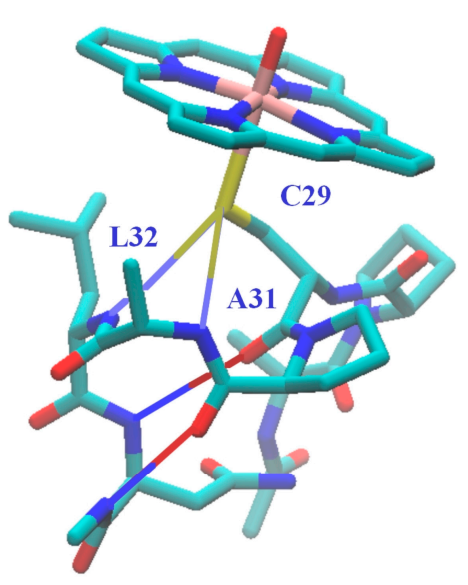

Figure 2. Bare-thiolate, CPO-I-A (a); and CPO-like, CPO-I-B (b) proximal pocket models of CPO-I.

The study of the 1S2R reaction pathway described above [21] clearly indicates that the effect of the secondary coordination sphere and proximal helix on the electron donating properties of the proximal thiolate is anisotropic in nature and hence may interfere differently with different chiral transition states. This observation provides a motivation for asking a rather unconventional question: Is it possible that the proximal environment may also have a significant effect on the enantiospecificity of a heme-thiolate-catalyzed epoxidation reaction? Herein, we address this question by comparing the combined effect of NH-S hydrogen bonding and the proximal helix's dipole moment on the rate-limiting barrier for the $1 \mathrm{R} 2 \mathrm{~S}$ doublet pathway of the CPO-catalyzed epoxidation of CBMS with the result for the 1S2R pathway obtained previously. CPO-I converts CBMS into the epoxide with $96 \%$ enantiomeric excess of the 1S2R over the 1R2S product [52], which corresponds to a free energy difference of $\sim 2.0 \mathrm{kcal} / \mathrm{mol}$ in favor of the $1 \mathrm{~S} 2 \mathrm{R}$ enantiomer at $300 \mathrm{~K}$. This underscores that significant levels of enantiospecificity can result from small free energy differences, making it difficult to identify the underlying causes of enantiospecificity with certainty. It is generally assumed that the distal 
binding site controls enantiospecificity by providing steric or specific interactions. In this paper, we shall show that in the case of CPO-catalyzed epoxidation of CBMS, the effect of the proximal pocket on the enantiospecificity is of the same order of magnitude $(\sim 1.0 \mathrm{kcal} / \mathrm{mol})$ as that of the distal pocket. Thus, it is possible that the effect of the proximal environment on the enantiospecificity of a heme-thiolate catalyzed epoxidation reaction may be significant. The underlying reason for this is that the secondary coordination sphere of the proximal thiolate and the dipole of the proximal helix determine the preferred electron transfer mechanism for the rate-limiting event. We found that in the case of CPO-I catalyzed epoxidation of CBMS, electron transfer to different oxyferryl $\pi^{*}$ orbitals results in the energy splitting of the transition states leading to the $1 \mathrm{R} 2 \mathrm{~S}$ and $1 \mathrm{~S} 2 \mathrm{R}$ product epoxides. This difference was not observed when the heme thiolate's secondary coordination sphere and the proximal helix were included in the model. In this case, the proximal NH-S bonds and helix dipole reduce the electron donating properties of the proximal thiolate. This reduction in electron donation, in effect an electron withdrawal, is greater for $\pi$ than for $\sigma$ orbitals and results in the electron transfer being to the $\mathrm{a}_{2 \mathrm{u}}+\sigma_{\mathrm{S}}$ rather than to a $\pi^{*}$ orbital. Due to this change in the electron transfer mechanism, the 1R2S and $1 S 2 R$ prechiral transition states become degenerate. We conclude that for heme-thiolate enzymes, the effect of the secondary coordination sphere and of the proximal helix on the electron-donating properties of the proximal thiolate ligand has to be included to provide quantitatively reliable energy differences for prechiral transition states.

Our work employs model systems, described in the Computational Methods section, chosen to isolate the influence of the heme thiolate's secondary coordination sphere and the proximal helix on CPO-I catalyzed epoxidation of CBMS. Thus, the model systems do not explicitly represent the distal binding pocket. We note that a large amount of conformational sampling is needed to quantify the influence of protein-CBMS steric interactions directly within meaningful margins of error. This is because steric interactions can fluctuate substantially relative to the small energy differences causing the enantiomeric excess. Our model-system approach allows us to focus on the influence of the proximal region without the conformational sampling issue.

\section{Computational Details}

\subsection{Methods}

Unrestricted DFT calculations of the doublet spin surfaces were carried out without symmetry restrictions using the B3LYP $[55,56]$ hybrid density functional (UB3LYP) with the LANL2DZ effective core potential (ECP) double- $\zeta$ basis set for Fe [57] and the 6-31G* basis set for $\mathrm{H}, \mathrm{C}, \mathrm{N}, \mathrm{O}$ [58] and $\mathrm{S}$ [59] atoms (basis set B0) using NWChem 6.1 software [60]. The stability of the density functions obtained was checked with the B0 basis set using Gaussian-09 [61]. The LANL2TZ + ECP triple- $\zeta$ basis set for Fe [62] and the 6-311++ $\mathrm{G}^{* *}$ basis set for H, C, N, O [63] and S [64] atoms (basis set B1) were used for energy refinement. Frequency calculations with basis set B0 were used to obtain zero point energy (ZPE) corrections, which are included in the energies of all stationary points given. Natural population analysis [65] (NPA) of spin/charge densities was carried out using NBO 6.0 software [66].

\subsection{CPO-I Models}

CPO-I was modeled as an $\mathrm{R}^{-}-\mathrm{Fe}^{4+} \mathrm{O}^{2-}\left(\mathrm{N}_{4} \mathrm{C}_{20} \mathrm{H}_{12}\right)^{-}$species in which the heme moiety lacks the vinyl and propionate side chains. This 43-atom model of CPO-I, CPO-I-A, employed $\mathrm{R}^{-}=\left(\mathrm{SCH}_{3}\right)^{-}$ (Figure 2) and constitutes the thiolate model, which lacks the axial sulfur's secondary coordination sphere and the proximal helix. The simulations of CPO-I-A were performed without geometric constraints. All transition state structures have one imaginary normal mode frequency, while all stable structures have only positive, real frequencies.

The CPO-I model used to study the proximal pocket effect (CPO-I-B) employed the $\mathrm{R}^{-}=\mathrm{CH}_{3}-\mathrm{NH}-\mathrm{Asn}-\mathrm{Leu}-\mathrm{Ala}-\mathrm{Pro}-\mathrm{Cys}^{-}-\mathrm{Pro}-\mathrm{Ala}-\mathrm{CO}-\mathrm{CH}_{3}$ peptide fragment (Figure 2B), which includes the proximal amino acid residues having $\mathrm{C}_{\alpha}$ atoms within $8 \AA$ of the proximal sulfur. Model 
$\mathrm{B}$ consists of 141 atoms and includes the secondary coordination sphere of the axial sulfur provided by the $\mathrm{A}_{31}: \mathrm{NH}-\mathrm{C}_{29}: \mathrm{S}$ and $\mathrm{L}_{32}: \mathrm{NH}-\mathrm{C}_{29}$ :S hydrogen bonds and the immediate steric environment of the axial sulfur, as well as the proximal $\alpha$-helix. The proximal $\alpha$-helix was included so that the dipole moment deriving from the $\mathrm{C}_{29}: \mathrm{CO}-\mathrm{N}_{33}: \mathrm{NH}$ and $\mathrm{P}_{30}: \mathrm{CO}-\mathrm{A}_{34}: \mathrm{NH}$ backbone hydrogen bonds is represented in the model. The full proximal $\alpha$-helix of $\mathrm{CPO}$ has 3 more hydrogen bonds formed by the backbone of residues 35 to 38 . These residues were not included due to computer resource limitations. Thus, the effect of the proximal helix dipole in our Model System B represents a lower bound to the actual effect. The proximal peptide fragment of CPO-I-B was constrained to maintain backbone and side-chain hydrogen bonds, backbone $\phi, \psi$ dihedrals and the orientation of the proximal helix relative to the heme moiety as in the crystal structure of CPO (PDB Code 1CPO) [24]. The stationary points of the CBMS/CPO-I-B reactant and transition state complexes have extra normal modes with imaginary frequencies caused by these constraints. The NH-S hydrogen bonds were not constrained. The details of the constraints applied are given in the Supplementary Materials (SM) (Data S1).

\subsection{Initial Structures for $1 R 2 S$ and $1 S 2 R$ CPO-I/CBMS Transition State Complexes}

For both Models $A$ and $B$, the $\mathrm{C}_{4}$ rotational symmetry of the porphyrin moiety results in four CPO-I/CBMS transition state complex conformations that are nearly degenerate in energy. In our previous work, we developed a molecular mechanics (MM) parameterization of the transition state using the quantum mechanics to molecular mechanics (Q2MM) method [67] and used it to dock the low spin CPO-I/CBMS transition state complex into the apoenzyme scaffold of CPO [18]. It was found that three of the four possible 1S2R CPO-I/CBMS transition state conformations were unrealistic because of significant steric overlap between CBMS and the distal pocket residues [18]. In this work, we used the same method to carry out the docking of four possible 1R2S CPO-I/CBMS low spin prechiral transition state conformations and found that, as for the 1S2R pathway, only one conformation is allowed by the steric restrictions of the distal pocket (Figure S1). The Cartesian coordinates of the 1R2S and 1S2R docked structures are given in the SM (Data S2A). The pertinent portions of these structures were used to initiate the fully quantum mechanical (QM) transition state searches on Model Systems A and B. The Cartesian coordinates of all stationary points are given in the SM (Data S2B).

\section{Results}

We have shown previously that, on the doublet surface, the epoxidation reaction takes place in two steps. The first and rate-limiting step is the formation of the $\mathrm{C}_{\beta}-\mathrm{O}$ bond, which is followed by the facile formation of the $\mathrm{C}_{\beta}-\mathrm{O}$ bond and ring closure [18]. The UB3LYP/B1/ / B0 potential energy surfaces (PES) connecting the reactant state (R) and the rate-limiting transition state (TS) leading to the formation of a $\mathrm{C}_{\beta}-\mathrm{O}$ bond were calculated for the doublet 1R2S pathway of CPO-I-A and CPO-I-B catalyzed epoxidation of CBMS. The transition states were found by scanning the $\mathrm{C}_{\beta}-\mathrm{O}$ distance followed by saddle-point optimization. The reactant states were found by optimizing along the transition mode of the TS in the direction of increasing $C_{\beta}-\mathrm{O}$ distance. The results calculated here for the 1R2S pathway were compared to those for 1S2R from our previous work [21]. For both Models $\mathrm{A}$ and $\mathrm{B}$ of CPO-I, the reactant states leading to the $1 \mathrm{R} 2 \mathrm{~S}$ and $1 \mathrm{~S} 2 \mathrm{R}$ products are CPO-I + CBMS bound complexes degenerate in energy and characterized by the weak interaction of the methyl group of CBMS and the oxygen of CPO-I; the transition states are the results of the oxyferryl radical attack on the $\mathrm{C}=\mathrm{C}$ double bond of the substrate (Figures 3 and 4). The natural spin densities and charges (Table 1) show that the 1R2S and 1S2R electron transfer mechanisms are identical. Furthermore, the $1 R 2 S$ spin densities and charges confirm our previous result for the 1S2R reaction [21], namely that for the CPO-I-B model the rate-limiting kinetic event is an electron transfer from the $\mathrm{C}=\mathrm{C} \pi$ bond to the $\mathrm{a}_{2 \mathrm{u}}+\sigma_{\mathrm{S}}$ thiolate-porphyrin orbital, while for the bare-thiolate CPO-I-A model, the electron is transferred to one of the oxyferryl $\pi^{*}$ orbitals. The important bond lengths of the stationary points are given in Table 1. The PESs and optimized structures for CPO-I-A and CPO-I-B catalyzed epoxidation of CBMS are shown in Figures 3 and 4, respectively. The PESs include ZPE corrections calculated 
at the UB3LYP/B0 level. For the bare-thiolate model, CPO-I-A, the calculations show that the 1R2S reaction pathway is favored by $1 \mathrm{kcal} / \mathrm{mol}$ (Figure 3). For CPO-I-B, the calculations show that the proximal pocket lowers the rate-limiting TS barrier by $3.7 \mathrm{kcal} / \mathrm{mol}$ on the doublet spin $1 \mathrm{R} 2 \mathrm{~S}$ surface, as compared to $4.6 \mathrm{kcal} / \mathrm{mol}$ calculated previously [21] for the doublet spin 1S2R surface. The influence of the proximal pocket thus removes the relative favorability that the 1R2S reaction pathway TS has in the absence of the apoprotein (Figure 4).

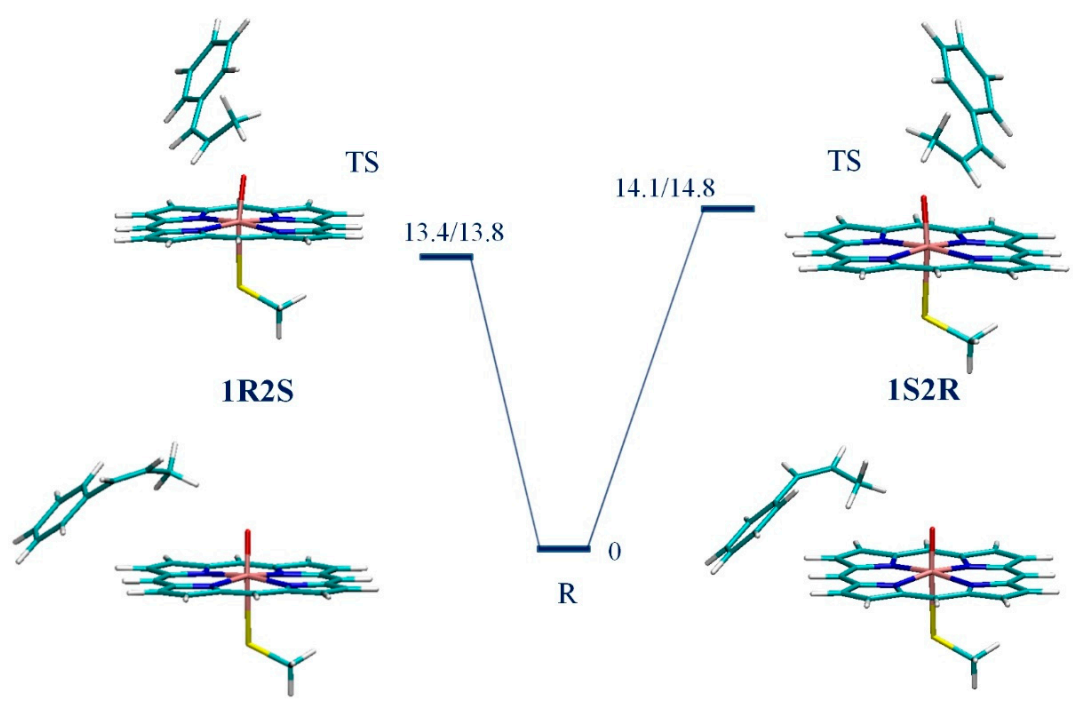

Figure 3. The UB3LYP/B1//B0 potential energy surfaces (in $\mathrm{kcal} / \mathrm{mol}$ ) connecting the reactant states $\mathrm{R}$ and the rate-limiting transition states TS leading to the formation of a $\mathrm{C}_{\beta}-\mathrm{O}$ bond on the doublet potential energy surfaces for epoxidation of $c$ s- $\beta$-methylstyrene (CBMS) by CPO-I-A to give 1R2S and $1 \mathrm{~S} 2 \mathrm{R}$ products.

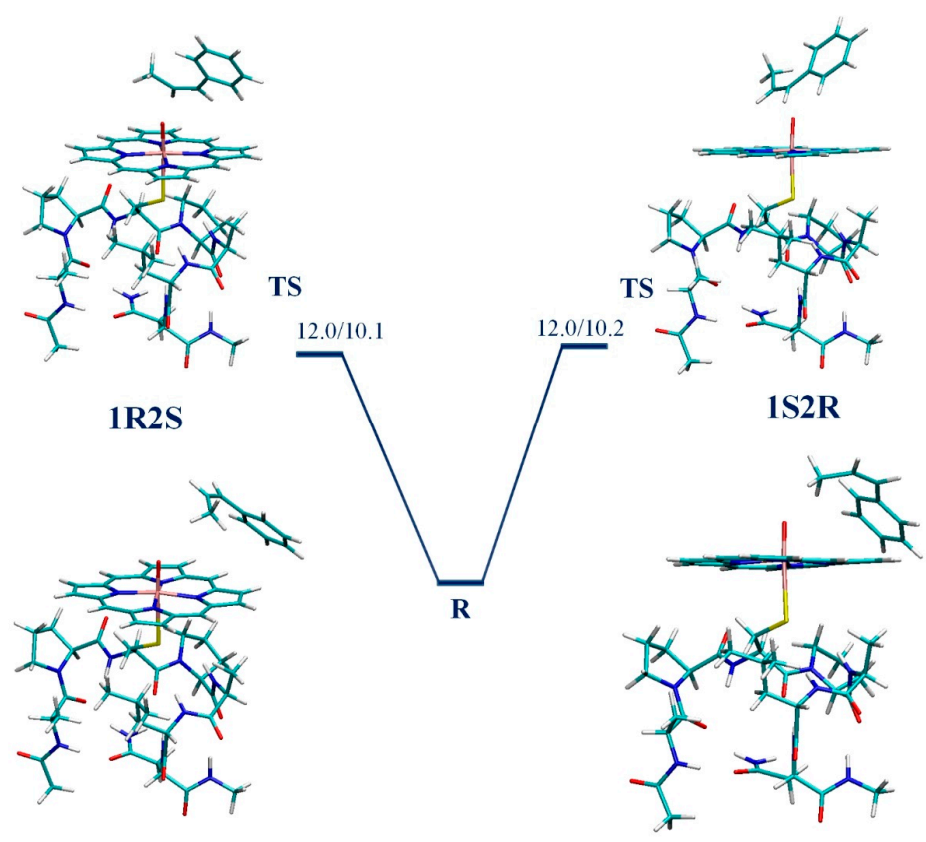

Figure 4. The UB3LYP/B1 / / B0 potential energy surfaces (in $\mathrm{kcal} / \mathrm{mol}$ ) connecting the reactant states $\mathbf{R}$ and the rate-limiting transition states TS leading to the formation of a $C_{\beta}-O$ bond on the doublet potential energy surfaces for 1R2S and 1S2R epoxidation of CBMS by CPO-I-B. 
Table 1. Natural group spin densities/charges and bond lengths $(\AA)$ of the optimized structures on the doublet spin potential energy surfaces (PES).

\begin{tabular}{|c|c|c|c|c|c|c|c|c|c|c|c|c|}
\hline & & \multicolumn{8}{|c|}{ Natural Spin Densities/Natural Atomic Charges } & \multicolumn{3}{|c|}{ Bond Lengths } \\
\hline & & S-R & Por & Fe & $\mathbf{O}$ & $\mathrm{C}_{\beta} \mathrm{H}$ & $\mathrm{C}_{\alpha} \mathrm{H}$ & $\mathbf{R}_{1}^{+}$ & $\mathbf{R}_{2}^{+}$ & S-Fe & $\mathrm{Fe}-\mathrm{O}$ & $\mathrm{O}-\mathrm{C}_{\beta}$ \\
\hline \multicolumn{13}{|c|}{ 1S2R } \\
\hline \multirow{2}{*}{$\mathbf{R}$} & A & $-0.75 /-0.05$ & $-0.30 /-0.49$ & $1.10 / 0.91$ & $0.95 /-0.37$ & $0.00 / 0.06$ & $0.00 /-0.03$ & $0.00 /-0.05$ & $0.00 / 0.02$ & 2.619 & 1.623 & - \\
\hline & $\mathrm{B}$ & $-0.60 /-0.27$ & $-0.50 /-0.32$ & $1.15 / 0.95$ & $0.95 /-0.36$ & $0.00 / 0.06$ & $0.00 /-0.03$ & $0.00 /-0.05$ & $0.00 / 0.02$ & 2.776 & 1.619 & - \\
\hline \multirow{2}{*}{ TS } & $\mathrm{A}$ & $-0.70 /-0.08$ & $-0.30 /-0.58$ & $0.95 / 0.90$ & $0.75 /-0.44$ & $-0.10 / 0.15$ & $0.30 / 0.04$ & $0.10 /-0.02$ & $0.00 / 0.03$ & 2.554 & 1.705 & 1.985 \\
\hline & $\mathrm{B}$ & $-0.30 /-0.40$ & $-0.25 /-0.51$ & $1.40 / 0.96$ & $0.50 /-0.42$ & $-0.05 / 0.18$ & $-0.20 / 0.08$ & $-0.10 / 0.07$ & $0.00 / 0.04$ & 2.570 & 1.658 & 2.099 \\
\hline \multicolumn{13}{|c|}{ 1R2S } \\
\hline \multirow{2}{*}{$\mathbf{R}$} & $\mathrm{A}$ & $-0.76 /-0.05$ & $-0.30 /-0.49$ & $1.10 / 0.91$ & $0.96 /-0.37$ & $0.00 / 0.06$ & $0.00 /-0.03$ & $0.00 /-0.05$ & $0.00 / 0.02$ & 2.624 & 1.623 & - \\
\hline & $\mathrm{B}$ & $-0.59 /-0.27$ & $-0.48 /-0.32$ & $1.15 / 0.95$ & $0.95 /-0.36$ & $0.00 / 0.06$ & $0.00 /-0.03$ & $0.00 /-0.05$ & $0.00 / 0.02$ & 2.776 & 1.619 & - \\
\hline \multirow{2}{*}{ TS } & $\mathrm{A}$ & $-0.65 /-0.08$ & $-0.28 /-0.59$ & $0.91 / 0.89$ & $0.76 /-0.43$ & $-0.11 / 0.15$ & $0.27 / 0.05$ & $0.10 /-0.01$ & $0.00 / 0.03$ & 2.512 & 1.702 & 1.996 \\
\hline & B & $-0.30 /-0.41$ & $-0.26 /-0.50$ & $1.38 / 0.96$ & $0.52 /-0.42$ & $-0.06 / 0.18$ & $-0.17 / 0.08$ & $-0.11 / 0.07$ & $0.00 / 0.04$ & 2.576 & 1.658 & 2.116 \\
\hline
\end{tabular}

S-R: proximal sulfur together with rest of $\mathrm{R}^{-}$moiety $\left(\mathrm{SCH}_{3}\right.$ for model A; sulfur with proximal helix for model B); Por: porphyrin; $\mathrm{R}_{1}^{+}$: benzylic group of CBMS; $\mathrm{R}_{2}^{+}$: methyl group of CBMS. 


\section{Discussion}

The experimentally-measured enantiomeric excesses of CPO-catalyzed epoxidations of various alkenes vary in the range $66 \%-97 \%$ [52]. This translates into free energy differences of $\sim 0-3 \mathrm{kcal} / \mathrm{mol}$ at room temperature, which is a small number compared to the thermal fluctuations of a typical 20,000-atom molecular model of the solvated CPO/substrate complex in an NPT simulation (number of atoms, pressure, and temperature constant), leading to the difficulty of accurate sampling. A comprehensive study of a stereoselective reaction should produce an accurate free energy potential surface that includes appropriate conformational averaging and connects substrate/enzyme, transition-state/enzyme and product/enzyme complexes. With current computational means, a molecular dynamics (MD) trajectory of $\sim 100 \mathrm{~ns}-\sim 1 \mu \mathrm{s}$ is achievable if a classical MM force field is employed, allowing the testing of the binding hypothesis, i.e., the notion that the favorability of substrate binding conformations parallels the enantiomeric excess of the epoxide product [68]. Previously, we carried out an extensive MM simulation to distinguish binding potential wells of the $\mathrm{CPO} / \mathrm{CBMS}$ complex from which the reaction to $1 \mathrm{~S} 2 \mathrm{R}$ and $1 \mathrm{R} 2 \mathrm{~S}$ epoxide products may occur; the flatness of the calculated free energy landscape rules out the binding hypothesis [17]. This is because CBMS floats relatively freely in the active site, as it is oriented by nonpolar interactions. It follows that the reaction is under kinetic control, and QM/MM transition state calculations are needed to identify the source of stereoselectivity. This presents a computational challenge, foremost because a substantial amount of conformational sampling is likely to be required to adequately reproduce the net influence of the distal region. For this purpose, a Q2MM model might be sufficient. However, as the present study shows, for heme-thiolate enzymes, an explicitly QM level of theory is required to account for the effect of the proximal region on the electron transfer mechanism.

The calculations presented here for CPO-I-A catalyzed epoxidation of CBMS on the doublet spin surface show that for the bare-thiolate model without the influence of the proximal pocket, CPO-I favors the formation of the $1 \mathrm{R} 2 \mathrm{~S}$ over the $1 \mathrm{~S} 2 \mathrm{R}$ enantiomer by $1 \mathrm{kcal} / \mathrm{mol}$. Since the bound complexes were found to be degenerate in energy, the transition states are the key to understanding this phenomenon. On the $1 R 2 S$ pathway, the $C=C \pi$ bond is attacked by the oxyferryl $\pi_{\mathrm{xz}}{ }^{*}$ electron, while on the 1S2R pathway, the attack is by the $\pi_{\mathrm{yz}}{ }^{*}$ electron (Figure 5). This stereo difference is the result of the restrictions imposed by the distal pocket on the possible orientation of the substrate in the 1R2S and 1S2R transition states with respect to the $\pi_{\mathrm{xz}}{ }^{*}$ and $\pi_{\mathrm{yz}}{ }^{*}$ orbitals (Figure 5). The electron transfer to the different $\pi^{*}$ orbitals results in the energy splitting of the 1R2S and 1S2R transition states because of uneven $\pi$-donation by the proximal thiolate ligand to these orbitals. When the proximal NH-S bonds and helix dipole are included by means of the CPO-I-B model, there is a larger withdrawing effect on $\pi$-donation than on $\sigma$-donation by the proximal thiolate. As a result, the electron from the $\mathrm{C}=\mathrm{C} \pi$ bond is transferred to the $\mathrm{a}_{2 \mathrm{u}}+\sigma_{\mathrm{S}}$ thiolate-porphyrin orbital, rather than to a $\pi^{*}$ orbital, for both the 1R2S and $1 \mathrm{~S} 2 \mathrm{R}$ channels. Hence, one would expect the chiral transition states to be degenerate, as we have found with the calculations presented.
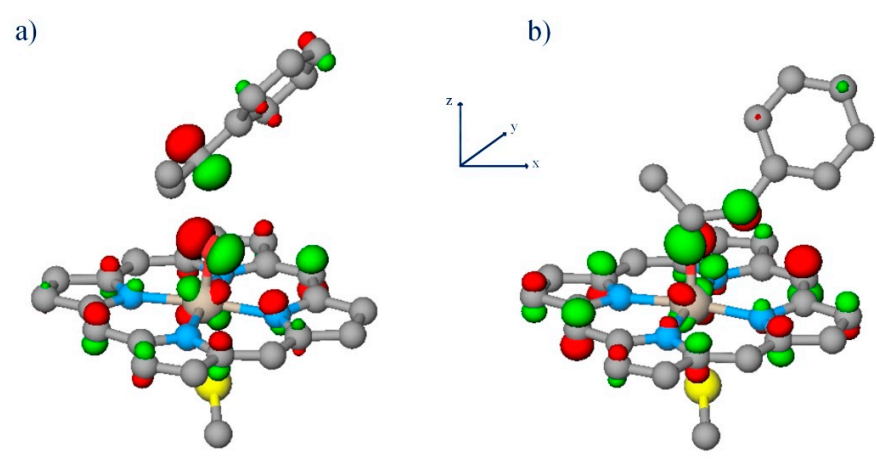

Figure 5. Oxyferryl $\pi^{*}$ attack on $\mathrm{C}=\mathrm{C}$ bond for model CPO-I-A: (a) LUMO in $\beta$ manifold of 1R2S TS; (b) LUMO in $\beta$ manifold of 1S2R TS. 


\section{Conclusions}

For heme-thiolate enzymes, contrary to the general understanding, the proximal region can have nearly as great an effect on the enantiospecificity of the epoxidation reaction as the distal region. This is possible because the proximal pocket determines the preferred electron transfer mechanism, which is either to the $\mathrm{a}_{2 \mathrm{u}}+\sigma_{S}$ orbital or to one of the $\pi^{*}$ orbitals. The latter case allows an interplay of the substrate orientation in the distal pocket with the asymmetry of $\pi$-donation by the proximal thiolate. In the case of $\mathrm{CPO}$, the calculated $1 \mathrm{kcal} / \mathrm{mol}$ difference in favor of the $1 \mathrm{R} 2 \mathrm{~S}$ enantiomer for the bare-thiolate (CPO-I-A) catalyzed epoxidation of CBMS on the low spin surface results in a difference of $\sim 3 \mathrm{kcal} / \mathrm{mol}$ with respect to the experimental value of $1.96 \mathrm{kcal} / \mathrm{mol}$ in favor of the $1 \mathrm{~S} 2 \mathrm{R}$ epoxide product, determined from the enantiomeric excess [52]. The experimental value reflects the total effect of the enzyme in favor of the 1S2R channel. The results for CPO-I-B catalyzed epoxidation of CBMS show that $\sim 1 \mathrm{kcal} / \mathrm{mol}$ out of the net $\sim 3 \mathrm{kcal} / \mathrm{mol}$ difference is due to the combined influence of the proximal thiolate's secondary coordination sphere (especially NH-S hydrogen bonding) and the proximal helix dipole. The inclusion of these factors reproduces the correct electron transfer mechanism. The remaining $\sim 2 \mathrm{kcal} / \mathrm{mol}$ presumably reflects the net influence of the distal pocket. Since the expected effect of the distal and proximal pockets of $\mathrm{CPO}$ are of the same order of magnitude, we conclude that proper modeling of the proximal pocket is necessary to correctly calculate the enantiospecificities of heme-thiolate-catalyzed epoxidations.

Supplementary Materials: Supplementary materials can be found at www.mdpi.com/1422-0067/17/8/1297/s1.

Acknowledgments: The authors would like to acknowledge the Instructional and Research Computing Center (IRCC) at Florida International University for providing computing resources that have contributed to the research results reported within this paper.

Author Contributions: Alexander N. Morozov contributed to simulation design and analysis, carried out the simulations, and drafted the initial manuscript. David C. Chatfield contributed to simulation design and analysis and to manuscript preparation, and he was responsible for manuscript submission.

Conflicts of Interest: The authors declare no conflict of interest.

\section{References}

1. Poulos, T.L. Heme enzyme structure and function. Chem. Rev. 2014, 114, 3919-3962. [CrossRef] [PubMed]

2. Shaw, P.D.; Hager, L.P. Biological chlorination. IV. Peroxidative nature of enzymatic chlorination. J. Am. Chem. Soc. 1959, 81, 1011-1012. [CrossRef]

3. Shaw, P.D.; Hager, L.P. Biological Chlorination. J. Biol. Chem. 1961, 236, 1626-1630.

4. Hager, L.P.; Morris, D.R.; Brown, F.S.; Eberwein, H. Chloroperoxidase II: Utilization of halogen ions. J. Biol. Chem. 1966, 241, 1769-1777. [PubMed]

5. Hofrichter, M.; Ullrich, R. Heme-thiolate haloperoxidases: Versatile biocatalysts with biotechnological and environmental significance. Appl. Microbiol. Biotechnol. 2006, 71, 276-288. [CrossRef] [PubMed]

6. Osborne, R.L.; Coggins, M.K.; Terner, J.; Dawson, J.H. Caldariomyces fumago chloroperoxidase catalyzes the oxidative dehalogenation of chlorophenols by a mechanism involving two one-electron steps. J. Am. Chem. Soc. 2007, 129, 14838-14839. [CrossRef] [PubMed]

7. Gruia, F.; Ionascu, D.; Kubo, M.; Ye, X.; Dawson, J.; Osborne, R.L.; Sligar, S.G.; Denisov, I.; Das, A.; Poulos, T.L.; et al. Low-frequency dynamics of caldariomyces fumago chloroperoxidase probed by femtosecond coherence spectroscopy. Biochem. 2008, 47, 5156-5167. [CrossRef] [PubMed]

8. Tzialla, A.A.; Kalogeris, E.; Gournis, D.; Sanakis, Y.; Stamatis, H. Enhanced catalytic performance and stability of chloroperoxidase from Caldariomyces fumago in surfactant free ternary water-organic solvent systems. J. Mol. Catal. B Enzym. 2008, 51, 24-35. [CrossRef]

9. Hager, L.P. A lifetime of playing with enzymes. J. Biol. Chem. 2010, 285, 14852-14860. [CrossRef] [PubMed]

10. Ayala, M.; Hernandez-Lopez, E.L.; Perezgasga, L.; Vazquez-Duhalt, R. Reduced coke formation and aromaticity due to chloroperoxidase-catalyzed transformation of asphaltenes from Maya crude oil. Fuel 2012, 92, 245-249. [CrossRef] 
11. Zhang, R.; He, Q.H.; Chatfield, D.; Wang, X.T. Paramagnetic nuclear magnetic resonance relaxation and molecular mechanics studies of the chloroperoxidase-indole complex: Insights into the mechanism of chloroperoxidase-catalyzed regioselective oxidation of indole. Biochemistry 2013, 52, 3688-3701. [CrossRef] [PubMed]

12. Liu, Y.; Wang, Y.; Jiang, Y.; Hu, M.; Li, S.; Zhai, Q. Biocatalytic synthesis of C3 chiral building blocks by chloroperoxidase-catalyzed enantioselective halo-hydroxylation and epoxidation in the presence of ionic liquids. Biotechnol. Prog. 2015, 31, 724-729. [CrossRef] [PubMed]

13. Muñoz-Guerrero, F.A.; Aguila, S.; Vazquez-Duhalt, R.; Campos, C.H.; Torres, C.C.; Alderete, J.B. Substrate ionization energy influences the epoxidation of $\mathrm{m}$-substituted styrenes catalyzed by chloroperoxidase from Caldariomyces fumago. Catal. Commun. 2016, 77, 52-54. [CrossRef]

14. Zhang, R.; He, Q.; Huang, Y.; Wang, X. Spectroscopic and QM/MM investigations of chloroperoxidase catalyzed degradation of orange G. Arch. Biochem. Biophys. 2016, 596, 1-9. [CrossRef] [PubMed]

15. Chen, H.; Hirao, H.; Derat, E.; Schlichting, I.; Shaik, S. Quantum mechanical/molecular mechanical study on the mechanisms of Compound I formation in the catalytic cycle of chloroperoxidase: An overview on heme enzymes. J. Phys. Chem. B 2008, 112, 9490-9500. [CrossRef] [PubMed]

16. Lai, W.; Chen, H.; Cho, K.B.; Shaik, S. Effects of substrate, protein environment, and proximal ligand mutation on Compound I and compound 0 of chloroperoxidase. J. Phys. Chem. A 2009, 113, 11763-11771. [CrossRef] [PubMed]

17. Morozov, A.N.; D'Cunha, C.; Alvarez, C.A.; Chatfield, D.C. Enantiospecificity of chloroperoxidase-catalyzed epoxidation: Biased molecular dynamics study of a cis- $\beta$-methylstyrene/chloroperoxidase-Compound I complex. Biophys. J. 2011, 100, 1066-1075. [CrossRef] [PubMed]

18. Morozov, A.N.; Chatfield, D.C. Chloroperoxidase-catalyzed epoxidation of cis- $\beta$-methylstyrene: Distal pocket flexibility tunes catalytic reactivity. J. Phys. Chem. B 2012, 116, 12905-12914. [CrossRef] [PubMed]

19. D'Cunha, C.; Morozov, A.N.; Chatfield, D.C. Theoretical study of HOCl-catalyzed keto-enol tautomerization of cyclopentanedione in an explicit water environment. J. Phys. Chem. A 2013, 117, 8437-8448. [CrossRef] [PubMed]

20. Pardillo, A.D.; Morozov, A.N.; Chatfield, D.C. Proximal pocket hydrogen bonds significantly influence the mechanism of chloroperoxidase Compound I formation. J. Phys. Chem. B 2015, 119, 12590-12602. [CrossRef] [PubMed]

21. Morozov, A.N.; Pardillo, A.D.; Chatfield, D.C. Chloroperoxidase-catalyzed epoxidation of cis- $\beta$-methylstyrene: $\mathrm{NH}-\mathrm{S}$ hydrogen bonds and proximal helix dipole change the catalytic mechanism and significantly lower the reaction barrier. J. Phys. Chem. B 2015, 119, 14350-14363. [CrossRef] [PubMed]

22. Rutter, R.; Hager, L.P. The detection of two electron paramagnetic resonance radical signals associated with chloroperoxidase Compound I. J. Biol. Chem. 1982, 257, 7958-7961. [PubMed]

23. Kim, S.H.; Perera, R.; Hager, L.P.; Dawson, J.H.; Hoffman, B.M. Rapid freeze-quench ENDOR study of chloroperoxidase Compound I: The site of the radical. J. Am. Chem. Soc. 2006, 128, 5598-5599. [CrossRef] [PubMed]

24. Sundaramoorthy, M.; Terner, J.; Poulos, T.L. The crystal structure of chloroperoxidase: A heme peroxidase-cytochrome P450 functional hybrid. Structure 1995, 3, 1367-1378. [CrossRef]

25. Sundaramoorthy, M.; Kishi, K.; Gold, M.H.; Poulos, T.L. The crystal-structure of manganese peroxidase from phanerochaete-chrysosporium at 2.06-angstrom resolution. J. Biol. Chem. 1994, 269, 32759-32767. [PubMed]

26. Poulos, T.L.; Finzel, B.C.; Howard, A.J. High-resolution crystal structure of cytochrome P450cam. J. Mol. Biol. 1987, 195, 687-700. [CrossRef]

27. Dawson, J.H. Probing structure-function relations in heme-containing oxygenases and peroxidases. Science 1988, 240, 433-439. [CrossRef] [PubMed]

28. McQuarters, A.B.; Wolf, M.W.; Hunt, A.P.; Lehnert, N. 1958-2014: After 56 years of research, cytochrome P450 reactivity is finally explained. Angew. Chem. Int. Ed. 2014, 53, 4750-4752. [CrossRef] [PubMed]

29. Groves, J.T. Enzymatic C-H bond activation: Using push to get pull. Nat. Chem. 2014, 6, 89-91. [CrossRef] [PubMed]

30. Harris, D.L.; Loew, G.H. Theoretical investigation of the proton assisted pathway to formation of cytochrome P450 Compound I. J. Am. Chem. Soc. 1998, 120, 8941-8948. [CrossRef] 
31. Kumar, D.; Karamzadeh, B.; Sastry, G.N.; de Visser, S.P. What factors influence the rate constant of substrate epoxidation by Compound I of cytochrome P450 and analogous iron(IV)-oxo oxidants? J. Am. Chem. Soc. 2010, 132, 7656-7667. [CrossRef] [PubMed]

32. Rydberg, P.; Sigfridsson, E.; Ryde, U. On the role of the axial ligand in heme proteins: A theoretical strudy. J. Biol. Inorg. Chem. 2004, 9, 203-223. [CrossRef] [PubMed]

33. Sono, M.; Roach, M.P.; Coulter, E.D.; Dawson, J.H. Heme-containing oxygenases. Chem. Rev. 1996, 96, 2841-2888. [CrossRef] [PubMed]

34. Poulos, T.L. The role of the proximal ligand in heme enzymes. J. Biol. Inorg. Chem. 1996, 1, 356-359. [CrossRef]

35. Ueno, T.; Nishikawa, N.; Moriyama, S.; Adachi, S.; Lee, K.; Okamura, T.; Ueyama, N.; Nakamura, A. Role of the invariant peptide fragment forming nhs hydrogen bonds in the active site of cytochrome P450 and chloroperoxidase: Synthesis and properties of cys-containing peptide Fe(III) and Ga(III) (octaethylporphinato) complexes as models. Inorg. Chem. 1999, 38, 1199-1210. [CrossRef] [PubMed]

36. Yoshioka, S.; Tosha, T.; Takahashi, S.; Ishimori, K.; Hori, H.; Morishima, I. Roles of the proximal hydrogen bonding network in cytochrome P450cam-catalyzed oxygenation. J. Am. Chem. Soc. 2002, 124, 14571-14579. [CrossRef] [PubMed]

37. Yoshioka, S.; Takahashi, S.; Ishimori, K.; Morishima, I. Roles of the axial push effect in cytochrome P450cam studied with the site-directed mutagenesis at the heme proximal site. J. Inorg. Biochem. 2000, 81, 141-151. [CrossRef]

38. Dey, A.; Jiang, Y.; Ortiz de Montellano, P.; Hodgson, K.O.; Hedman, B.; Solomon, E.I. S K-edge XAS and DFT calculations on cytochrome P450: Covalent and ionic contributions to the cysteine-Fe bond and their contribution to reactivity. J. Am. Chem. Soc. 2009, 131, 7869-7878. [CrossRef] [PubMed]

39. Galinato, M.G.I.; Spolitak, T.; Ballou, D.P.; Lehnert, N. Elucidating the role of the proximal cysteine hydrogen-bonding network in ferric cytochrome P450cam and corresponding mutants using magnetic circular dichroism spectroscopy. Biochemistry 2011, 50, 1053-1069. [CrossRef] [PubMed]

40. De Visser, S.P.; Ogliaro, F.; Sharma, P.K.; Shaik, S. Hydrogen bonding modulates the selectivity of enzymatic oxidation by P450: Chameleon oxidant behavior by Compound I. Angew. Chem. Int. Ed. 2002, 124, 11809-11826.

41. De Visser, S.P.; Ogliaro, F.; Sharma, P.K.; Shaik, S. What factors affect the regioselectivity of oxidation by cytochrome P450? A DFT study of allylic hydroxylation and double bond epoxidation in a model reaction. J. Am. Chem. Soc. 2002, 130, 12961-12974. [CrossRef] [PubMed]

42. De Visser, S.P.; Tan, L.S. Is the bound substrate in nitric oxide synthase protonated or neutral and what is the active oxidant that performs substrate hydroxylation? J. Am. Chem. Soc. 2008, 130, 12961-12974. [CrossRef] [PubMed]

43. Latifi, R.; Sainna, M.A.; Rybak-Akimova, E.V.; de Visser, S.P. Does hydrogen-bonding donation to manganese(IV)-oxo and iron(IV)-oxo oxidants affect the oxygen-atom transfer ability? a computational study. Chem. Eur. J. 2013, 19, 4058-4068. [CrossRef] [PubMed]

44. Hol, W.G.J.; van Duijnen, P.T.; Berendsen, H.J.C. The $\alpha$-Helix dipole and the properties of proteins. Nature 1978, 273, 443-446. [CrossRef] [PubMed]

45. Park, C.; Goddard, W.A. Stabilization of $\alpha$-helices by dipole-dipole interactions within $\alpha$-helices. J. Phys. Chem. B 2000, 104, 7784-7789. [CrossRef]

46. Hol, W.G.J.; Halie, L.M.; Sander, C. Dipoles of the $\alpha$-helix and $\beta$-sheet: Their role in protein folding. Nature 1981, 294, 532-536. [CrossRef] [PubMed]

47. Morozov, A.N.; Shiu, Y.J.; Liang, C.T.; Tsai, M.Y.; Lin, S.H. Nonadditive interactions in protein folding: The zipper model of cytochrome C. J. Biol. Phys. 2007, 33, 255-270. [CrossRef] [PubMed]

48. Tsai, M.Y.; Morozov, A.N.; Chu, K.Y.; Lin, S.H. Molecular dynamics insight into the role of tertiary (foldon) interactions on unfolding in cytochrome C. Chem. Phys. Lett. 2009, 475, 111-115. [CrossRef]

49. Morozov, A.N.; Roach, J.P.; Kotzer, M.; Chatfield, D.C. A possible mechanism for redox control of human neuroglobin activity. J. Chem. Inf. Model. 2014, 54, 1997-2003. [CrossRef] [PubMed]

50. Lockhart, D.J.; Kim, P.S. Internal stark effect measurement of the electric field at the amino terminus of an $\alpha$-helix. Science 1992, 257, 947-951. [CrossRef] [PubMed] 
51. Ueno, T.; Kousumi, Y.; Yoshizawa-Kumagaye, K.; Nakajima, K.; Ueyama, N.; Okamura, T.; Nakamura, A. Role of $\alpha$-helix conformation cooperating with NH..S hydrogen bond in the active site of cytochrome P-450 and chloroperoxidase: Synthesis and Properties of [M $\mathrm{M}^{\mathrm{III}}(\mathrm{OEP})(\mathrm{Cys}-\mathrm{Helical}$ Peptide)] (M = Fe and Ga). J. Am. Chem. Soc. 1998, 120, 12264-12273. [CrossRef]

52. Allain, E.J.; Hager, L.P.; Deng, L.; Jacobsen, E.N. Highly enantioselective epoxidation of disubstituted alkenes with hydrogen peroxide catalyzed by chloroperoxidase. J. Am. Chem. Soc. 1993, 115, 4415-4416. [CrossRef]

53. Hu, S.; Hager, L.P. Asymmetric epoxidation of functionalized cis-olefins catalyzed by chloroperoxidase. Tetrahedron Lett. 1999, 40, 1641-1644. [CrossRef]

54. Shaik, S.; Cohen, S.; Wang, Y.; Chen, H.; Kumar, D.; Thiel, W. P450 Enzymes: Their structure, reactivity, and selectivity modeled by QM/MM calculations. Chem. Rev. 2010, 110, 949-1017. [CrossRef] [PubMed]

55. Becke, A.D. Density-functional thermochemistry. III. The role of exact exchange. J. Chem. Phys. 1993, 98, 5648-5652. [CrossRef]

56. Lee, C.; Yang, W.; Parr, R.G. Development of the colle-salvetti correlation-energy formula into a functional of the electron density. Phys. Rev. B 1988, 37, 785-789. [CrossRef]

57. Hay, P.J.; Wadt, W.R. Ab initio effective core potentials for molecular calculations. Potentials for K to Au including the outermost core orbitals. J. Chem. Phys. 1985, 82, 299-310. [CrossRef]

58. Hariharan, P.C.; Pople, J.A. The influence of polarization functions on molecular orbital hydrogenation energies. Theor. Chim. Acta 1973, 28, 213-222. [CrossRef]

59. Francl, M.M.; Pietro, W.J.; Hehre, W.J.; Binkley, J.S.; Gordon, M.S.; DeFrees, D.J.; Pople, J.A. Self-consistent molecular orbital methods. XXIII. A polarization-type basis set for second-row elements. J. Chem. Phys. 1982, 77, 3654-3665. [CrossRef]

60. Valiev, M.; Bylaska, E.J.; Govind, N.; Kowalski, K.; Straatsma, T.P.; van Dam, H.J.J.; Wang, D.; Nieplocha, J.; Apra, E.; Windus, T.L.; et al. NWChem: A comprehensive and scalable open-source solution for large scale molecular simulations. Comput. Phys. Commun. 2010, 181, 1477-1489. [CrossRef]

61. Frisch, M.J.; Trucks, G.W.; Schlegel, H.B.; Scuseria, G.E.; Robb, M.A.; Cheeseman, J.R.; Scalmani, G.; Barone, V.; Mennucci, B.; Petersson, G.A.; et al. Gaussian 09, Revision A.1; Gaussian, Inc.: Wallingford, UK, 2009.

62. Hay, P.J.; Wadt, W.R. Ab initio effective core potentials for molecular calculations. Potentials for the transition metal atoms Sc to Hg. J. Chem. Phys. 1985, 82, 270-283. [CrossRef]

63. Krishnan, R.; Binkley, J.S.; Seeger, R.; Pople, J.A. Self - consistent molecular orbital methods. XX. A basis set for correlated wave functions. J. Chem. Phys. 1980, 72, 650-654. [CrossRef]

64. McLean, A.D.; Chandler, G.S. Contracted gaussian basis sets for molecular calculations. I. Second row atoms, $Z=11-18$. J. Chem. Phys. 1980, 72, 5639-5648. [CrossRef]

65. Foster, J.P.; Weinhold, F. Natural Hybrid Orbitals. J. Am. Chem. Soc. 1980, 102, 7211-7218. [CrossRef]

66. Glendening, E.D.; Landis, C.R.; Weinhold, F. NBO 6.0: Natural Bond Orbital Analysis Program. J. Comput. Chem. 2013, 34, 1429-1437. [CrossRef] [PubMed]

67. Norrby, P.O. Selectivity in asymmetric synthesis from QM-guided molecular mechanics. J. Mol. Struct. Theochem. 2000, 506, 9-16. [CrossRef]

68. Fruetel, J.A.; Collins, J.R.; Camper, D.L.; Loew, G.H.; Ortiz de Montellano, P.R. Calculated and experimental absolute stereochemistry of the styrene and $\beta$-methylstyrene epoxides formed by cytochrome P450cam. J. Am. Chem. Soc. 1992, 114, 6987-6993. [CrossRef]

(C) 2016 by the authors; licensee MDPI, Basel, Switzerland. This article is an open access article distributed under the terms and conditions of the Creative Commons Attribution (CC-BY) license (http://creativecommons.org/licenses/by/4.0/). 